\title{
Kapitalisme, Krisis Ekologi, dan Keadilan Intergenerasi: Analisis Kritis atas Problem Pengelolaan Lingkungan Hidup di Indonesia
}

\section{(Capitalism, Ecological Crises, and Inter-Generational Justice: Critical Analysis on the Environmental Management Problems in Indonesia)}

\author{
Lailiy Muthmainnah \\ Rizal Mustansyir \\ Sindung Tjahyadi \\ Fakultas Filsafat - Universitas Gadjah Mada \\ Jalan Sosio-Humaniora No.1, Bulak Sumur, Yogyakarta 55281 \\ Tel.: +62 (274) 50068 \\ Surel : lailiy@ugm.ac.id
}

Diterima: 22 Oktober 2019 Direvisi: 17 April 2020 Disetujui: 25 Juni 2020

\begin{abstract}
Abstrak
Penelitian ini bertujuan untuk menganalisis secara kritis problem pengelolaan lingkungan hidup di Indonesia sebagai bagian dari krisis ekologi global dan konsekuensinya terhadap isu keadilan intergenerasi. Untuk mencapai tujuan tersebut digunakan metode fenomenologi dengan unsur-unsur metodis interpretasi, induksi-deduksi, refleksi, idealisasi, dan heuristika. Berdasarkan penelitian yang telah dilakukan, dapat disimpulkan bahwa terjadinya problem pengelolaan lingkungan hidup di Indonesia yang semakin mengarah pada kondisi krisis ekologi tidak hanya disebabkan oleh paradigma pengelolaan yang masih antroposentris, tetapi juga akibat dari ketimpangan akses dan distribusi sumber daya serta kapital. Pemanfaatan sumber daya didominasi oleh sekelompok kecil masyarakat yang menguasai kapital dan meminggirkan peran serta masyarakat lokal. Akibatnya, terjadi eksploitasi alam oleh manusia yang merupakan turunan dari eksploitasi manusia atas manusia. Kondisi ini tidak saja membahayakan generasi sekarang, tetapi juga generasi yang akan datang. Untuk itu perlu dirumuskan kembali prinsip-prinsip dasar dalam politik pengelolaan lingkungan di Indonesia yang mampu mengantisipasi dua tipe eksploitasi tersebut sehingga mampu mengantisipasi tuntutan keadilan inter-generasi.
\end{abstract}

Kata kunci: kapitalisme, keadilan inter-generasi, krisis ekologi, lingkungan hidup

\begin{abstract}
This study aims to critically analyze the problem of environmental management in Indonesia as a part of global ecological crises and its consequences for the issue of inter-generational justice. To achieve the objective of the study, a phenomenological method is used together with methodical elements of interpretation, induction-deduction, reflection, idealization, and heuristics. This study finds that the occurrence of environmental management problems in Indonesia which increasingly leads to ecological crisis conditions are not only caused by the management paradigm that is still anthropocentric, but also as a result of unequal access and distribution of resources and capital.
\end{abstract}


Utilization of resources is dominated by a small group of people who control capital and marginalize the participation of local communities. Hence, there is a natural exploitation by humans which is a derivative of human exploitation of humans. This condition endangers not only the present generation, but also the posterity. In conclusion, it is necessary to reformulate the basic principles in environmental management politics in Indonesia that are able to anticipate these two types of exploitation to anticipate demands for inter-generational justice.

Keywords: environment, capitalism, ecological crisis, inter-generational justice.

\section{PENDAHULUAN}

Pasal 1 UU No. 32 Tahun 2009 tentang Perlindungan dan Pengelolaan Lingkungan Hidup mendefinisikan bahwa lingkungan hidup adalah kesatuan ruang dengan semua benda, daya, keadaan, dan makhluk hidup, termasuk manusia dan perilakunya yang memengaruhi alam itu sendiri, kelangsungan perikehidupan, dan kesejahteraan manusia serta makhluk hidup lain. Berdasarkan definisi tersebut, dapat dipahami bahwa lingkungan hidup memiliki makna yang sangat luas karena menyangkut keseluruhan interaksi kehidupan alam semesta, yaitu antara manusia dengan manusia yang mempunyai dampak pada alam, serta antara manusia dengan makhluk hidup lain yang ada di planet Bumi atau dengan alam secara keseluruhan. Pada konteks interaksi ini manusia memiliki tanggung jawab moral yang sangat besar karena perilaku manusia dalam hubungannya dengan alam dan makhluk hidup lain akan sangat menentukan kualitas lingkungan hidup (Keraf 2005:26).

Fakta menunjukkan bahwa semakin tingginya tingkat kerusakan lingkungan hidup berjalan seiring dengan perkembangan gagasan tentang modernitas. Pada konteks Indonesia, kondisi ini dapat dilihat secara jelas pada pilihan orientasi pembangunan, baik fase Orde Baru maupun Reformasi. Orde Baru secara tegas mengadopsi gagasan modernitas ala W. W. Rostow dengan the stages of economic growth, yang kemudian dituangkan dalam kebijakan Pembangunan Lima Tahun (PELITA). Konsekuensi dari diadopsinya gagasan modernitas tersebut adalah dikembangkannya industri dalam skala masif. Untuk mendukung kebijakan tersebut, berbagai sumber daya alam yang ada dieksploitasi sedemikian rupa sehingga mampu mendukung proses industrialisasi sebagai motor penggerak utama ke arah terwujudnya masyarakat modern (Fakih 2006:55). Konsekuensi yang tidak dapat dihindari dari hal tersebut di atas adalah kerusakan lingkungan hidup dalam skala luas. Sebagai contoh, laju deforestasi yang terjadi selama Orde Baru berkuasa terus meningkat secara signifikan dari tahun ke tahun. Berdasarkan catatan FAO, disebutkan bahwa antara tahun 1976-1980 angka deforestasi mencapai 550.000 hektar/tahun. Jumlah ini semakin meningkat dari tahun ke tahun, yaitu menjadi 1 juta hektar/tahun pada tahun 1980; 1,2 juta hektar/tahun pada tahun 1985; hingga 1,7 hektar/tahun pada 1985-1997. Peningkatan laju deforestasi tersebut berjalan seiring dengan penambahan jumlah pemegang konsesi HPH di Indonesia (Hidayat 2011:136). Sementara itu, pada Orde Reformasi, angka deforestasi juga masih sangat tinggi, yaitu 3,52 juta hektar/tahun pada periode 1997-2000; dan 1,09 juta hektar/tahun pada tahun 2014-2015. Kondisi ini menempatkan Indonesia sebagai penyumbang emisi gas karbon terbesar keenam di dunia (Forest Watch Indonesia 2018:6).

Hal tersebut di atas hanyalah salah satu contoh pola pengelolaan lingkungan yang buruk dan menimbulkan dampak lingkungan dalam skala luas. Sesungguhnya masih banyak contoh lain yang menunjukkan kondisi senada dengan hal tersebut di atas, seperti misalnya yang terjadi pada bidang pertambangan dan perkebunan sawit. Eksploitasi tambang batubara yang menyisakan lubang bekas galian tambang tidak hanya menyebabkan kerusakan lingkungan, tetapi juga membahayakan keselamatan masyarakat di sekitar lokasi. Sebagai contoh, lokasi tambang batubara di Kalimantan Timur yang telah menimbulkan korban sebanyak 31 orang dari 2011 hingga 2018 (Maimunah 2018). Sementara itu, ekspansi lahan sawit juga terus terjadi pasca-Reformasi. Berdasarkan data Indonesia 
Palm Oil Statistic, luasan lahan sawit pada tahun 2006 yaitu 6,59 juta hektar dan secara signifikan meningkat menjadi 11,44 juta hektar pada tahun 2015 (Utami 2017:115). Eksistensi sawit yang memiliki nilai ekonomis tinggi menjadi faktor utama terjadinya konversi lahan hutan di berbagai wilayah di Indonesia, seperti di Kalimantan Timur, Maluku Utara, dan Sumatera Utara (Forest Watch Indonesia 2018).

Kondisi-kondisi tersebut di atas menunjukkan bahwa modernitas dengan fondasi rasionalitas telah menempatkan alam sebagai sumber daya yang dapat dieksploitasi manusia. Kekuasaan dalam konteks ini hanya dimiliki oleh manusia dan tidak pada entitas lain di luar manusia. Hal ini membawa manusia pada pola pikir yang tidak hanya rasional, tetapi juga positifistik, dan optimistik. Alam dipandang sebagai hal yang dapat diatur sedemikian rupa oleh manusia dan selalu dapat ditaklukkan karena manusia akan selalu mampu menciptakan berbagai terobosan teknologi untuk mengatasi persoalan-persoalan yang muncul. Sayangnya, nalar ini ternyata salah karena fakta menunjukkan bahwa kondisi alam sekarang menjadi lebih sulit diprediksi seiring dengan turunnya daya dukung alam. Kondisi ini kemudian memunculkan ancaman tidak hanya bagi generasi yang ada sekarang tetapi juga generasi yang akan datang.

Modernitas, industrialisasi, dan kapitalisasi merupakan tiga hal yang berjalan dalam satu tarikan nafas. Betapa tidak, proses modernisasi senantiasa mensyaratkan adanya industrialisasi sebagai motor penggerak utama. Sementara itu, untuk mendukung industrialisasi, eksploitasi berbagai sumber daya alam akan dilakukan secara masif. Hal ini sebagaimana dipaparkan oleh W. W. Rostow (1959) dalam karyanya yang berjudul The Stages of Economic Growth. Selanjutnya, untuk melakukan industrialisasi dibutuhkan kecukupan modal sehingga pintu investasi harus dibuka lebar. Ketika investasi dibuka, tidak dapat dihindari bahwa ruang tersebut akan didominasi oleh para pemilik modal dibandingkan masyarakat lokal. Pada titik inilah ketimpangan sudah dimulai dan seterusnya akan berlanjut menjadi sebuah proses dominasi.

Proses modernisasi yang tidak dapat menghindar dari proses akumulasi kapital oleh sekelompok kecil golongan ini kemudian membawa konsekuensi lebih lanjut pada terjadinya dominasi dan eksploitasi sumberdaya secara luar biasa. Ketika kondisi ini dibiarkan terus berlanjut, yang akan terjadi adalah kesenjangan yang semakin melebar serta degradasi lingkungan yang semakin mendekati titik nadir. Hal ini tentu menjadi ancaman tidak hanya bagi sebuah bangsa tetapi juga seluruh masyarakat manusia. Tidak hanya generasi sekarang, tetapi juga generasi yang akan datang. Oleh karena itu, penting untuk dirumuskan kerangka dasar dalam pengelolaan sumber daya alam yang akan digunakan sebagai pijakan untuk membawa pada kondisi yang lebih adil, baik bagi generasi sekarang maupun generasi yang akan datang.

\section{METODE}

Penelitian ini merupakan kajian filosofis atas problem aktual pengelolaan lingkungan hidup di Indonesia, khususnya yang terkait dengan pengelolaan sumber daya alam. Adapun metode yang digunakan adalah fenomenologi. Prinsip kerja metode fenomenologi adalah berupaya menganalisis secara deskriptif dan introspektif tentang segala bentuk kesadaran manusia dan pengalamannya, baik dari aspek inderawi, konseptual, moral, estetis, dan religius. Fenomenologi adalah sebuah metodologi kualitatif yang mengizinkan peneliti menerapkan dan mengaplikasikan kemampuan subjektivitas dan interpersonalnya dalam proses penelitian eksplanatori (Alase 2017).

Selanjutnya, pada tahapan analisis peneliti menggunakan unsur-unsur metodis sebagai berikut (Bakker 1990: 62): 
a. Interpretasi: peneliti berusaha memahami makna yang terkandung dalam data untuk menemukan situasi problematis, berupa struktur hakiki serta nilai-nilai dasar yang berperan di dalam problem aktual pengelolaan lingkungan hidup di Indonesia.

b. Induksi dan deduksi: proses ini berjalan secara sinergis, dalam arti ketika data telah dikumpulkan oleh peneliti dan dilakukan identifikasi serta kategorisasi untuk menemukan problem nilai yang ada dalam problem pengelolaan lingkungan hidup di Indonesia, maka pada saat yang bersamaan hal ini juga diperkuat dengan tinjauan konkret atas berbagai situasi dan kondisi yang terjadi akibat dari problem tersebut.

c. Refleksi dan Idealisasi: Setelah diketahui dan dipahami situasi yang terjadi dalam objek material yang diteliti, selanjutnya ditemukan berbagai macam inkonsistensi, ketidakselarasan, atau pun penyimpangan. Berdasarkan hal ini, dapat disusun sebuah konsepsi filosofis yang bersifat korektif menuju ke arah idealisasi konsep tertentu.

d. Heuristika: berdasarkan tahapan-tahapan yang telah dilakukan sebelumnya, peneliti kemudian merumuskan ke dalam konsep baru yang representatif dan proporsional serta dapat dipertanggungjawabkan secara filosofis.

\section{HASIL DAN PEMBAHASAN}

\section{Spirit Modernitas dan Pola Pengelolaan Lingkungan Hidup di Indonesia}

Sejarah pengelolaan atau mungkin lebih tepatnya "eksploitasi" sumber daya alam dan lingkungan hidup di Indonesia telah dimulai sejak ditetapkannya Undang Undang No. 1 Tahun 1967 yang mengatur tentang Penanaman Modal Asing (PMA) dan kemudian disusul dengan Undang-Undang No. 6 Tahun 1968 tentang Penanaman Modal Dalam Negeri (PMDN). Dibukanya keran investasi pada awal pemerintahan Orde Baru tersebut kemudian membawa implikasi yang luar biasa pada eksploitasi berbagai sumber daya alam yang ada di Indonesia yang berimbas pada rusaknya lingkungan hidup secara masif.

Pemerintah Orde Baru menggunakan ideologi modernis dalam menjalankan roda pemerintahannya. Pembangunan dimaknai sebagai upaya perubahan masyarakat dari tradisional menuju masyarakat modern, sehingga orientasi pembangunan hanyalah pertumbuhan ekonomi. Untuk mendukung tuntutan pertumbuhan ekonomi ini, pemerintah kemudian melakukan eksploitasi berbagai sumber daya alam yang dimiliki. Sebagai contoh, eksploitasi yang terjadi di sektor kehutanan. Pengelolaan hasil hutan di Indonesia sampai dengan awal tahun 1980-an dijual dalam bentuk kayu gelondongan (log) dengan jumlah mencapai lebih dari 70\% total hasil kayu. Pendapatan Indonesia dari penjualan kayu $\log$ tersebut mencapai 6 juta US dolar pada tahun 1966 dan bertambah menjadi 564 juta US dolar pada tahun 1974, dan di penghujung tahun 1979 mencapai 2,1 miliar US dolar. Pada fase inilah Indonesia mengalami "panen emas hijau." Meskipun demikian, kondisi ini sangat memprihatikan karena Indonesia mengimpor kayu tersebut dalam bentuk kayu mentah dan bukan dalam bentuk kayu olahan. Oleh karena itu, untuk meningkatkan nilai tambah, pada tahun 1985 pemerintah mengeluarkan kebijakan untuk melarang ekspor kayu log. Kebijakan ini kemudian mampu mendorong industri pengolahan kayu nasional sehingga ekspor produk olahan kayu Indonesia, khususnya kayu lapis, mampu menjadi market leader antara kisaran tahun 1987-1997 (Nurrochmat 2010:9).

Seiring dengan kebijakan tersebut, di sektor hulu, jumlah pemilik konsesi HPH juga terus bertambah. Pada tahun 1968 pemerintah memberikan 18 izin konsesi dengan jumlah areal hutan 2 juta hektar, kemudian pada tahun 1972 berkembang menjadi 101 unit konsesi dengan luas area 31 juta hektar. Pada tahun 1988 izin konsesi bertambah lagi menjadi 538 konsesi dengan luas area 55 juta hektar, dan pada tahun 1990-an menjadi 657 izin konsesi dengan luas area 69 juta hektar. Dari jumlah 657 izin konsesi tersebut, 51,6\% (luasan hutan produksi) hanya dikuasai oleh 20 unit perusahaan besar 
(Hidayat 2011:114). Kondisi ini jelas menunjukkan ketimpangan distribusi sumber daya. Selain itu, peningkatan konsesi $\mathrm{HPH}$ juga sekaligus menunjukkan tingkat kerusakan areal hutan yang mengalami kenaikan signifikan. Menurut catatan Walhi, kerusakan hutan terus mengalami peningkatan seiring dengan kebijakan untuk eksploitasi hutan. Pada tahun 1970-an kerusakan hutan adalah 300.000 hektar/tahun, pada tahun 1980-an meningkat menjadi 600.000 hektar/tahun, dan pada tahun 1990-an meningkat tajam menjadi 1,5 hingga 2 juta hektar/tahun (Hidayat 2011:86).

Kondisi tersebut di atas menunjukkan bahwa orientasi pemerintah kala itu adalah pada sektor ekonomi saja. Maka, tidak heran apabila kerusakan lingkungan terjadi secara cepat dan masif. Pengaturan terkait pengelolaan lingkungan hidup baru muncul pada tahun 1982, yaitu dengan ditetapkannya Undang-Undang No. 4 Tahun 1982 tentang Ketentuan-Ketentuan Pokok Pengelolaan Lingkungan Hidup, yang kemudian diganti dengan Undang-Undang No. 23 Tahun 1997 tentang Pengelolaan Lingkungan Hidup. Namun pada praktiknya, UU tersebut tidak bertaring tatkala harus berhadapan dengan UU yang bersifat sektoral seperti UU Kehutanan, Pertambangan, dan lainnya. Pada banyak kasus justru banyak ditemukan ketidaksinkronan antara UU pengelolaan Lingkungan Hidup dengan UU sektoral yang muncul sebagai justifikasi penguasa untuk melakukan eksploitasi berbagai sumberdaya alam yang ada.

Beralih pada Orde Reformasi, pemerintah melakukan perubahan pola pengelolaan lingkungan dengan menetapkan Undang-Undang No. 32 tahun 2009 tentang Perlindungan dan Pengelolaan Lingkungan Hidup. Kemunculan UU ini diyakini lebih prorakyat dan prolingkungan. Namun, persoalan yang sama muncul ketika UU tersebut berbenturan dengan UU yang sektoral. Orientasi pembangunan yang tetap mengedepankan pencapaian pertumbuhan ekonomi pada akhirnya membuat spirit UU No. 32 tahun 2009 menjadi tidak bermakna. Ketika muncul persoalan antara aspek kelestarian lingkungan dan aspek ekonomi, dapat dipastikan bahwa pertimbangan utama yang digunakan adalah ekonomi. Maka, tidak mengherankan jika kondisi tersebut kemudian memicu timbulnya konflik di masyarakat. Berdasarkan data Walhi, pada tahun 2017 lima urutan teratas pemicu konflik di masyarakat adalah problem pencemaran, pertambangan, kehutanan, perikanan, dan perkebunan (Walhi 2018).

Selain itu, kondisi ketimpangan akses sumber daya juga masih terjadi di era Reformasi. Data Walhi pada tahun 2017 tentang penguasaan ruang investasi di Indonesia menyebutkan bahwa Indonesia yang memiliki luas daratan 191.944.000 hektar dan luas laut 327.381 .000 hektar, dari total luas wilayah Indonesia tersebut 30,65\%-nya telah diusahakan atau setara dengan 159.178.237 hektar. Berdasarkan total luas izin usaha yang telah dikeluarkan oleh pemerintah tersebut di atas, yaitu 159.178.237 hektar, 82,91\%-nya telah dialokasikan untuk korporasi, yang meliputi pertambangan migas, kehutanan, pertambangan, dan perkebunan sawit (Walhi 2018).

Fakta tersebut di atas semakin menunjukkan bahwa pola pengelolaan lingkungan yang diadopsi di Indonesia sejauh ini masih terjebak pada tuntutan pertumbuhan ekonomi. Meskipun telah dimulai upaya ke arah sustainable development melalui penetapan UU No. 32 tahun 2009 tentang Perlindungan dan Pengelolaan Lingkungan Hidup, akibat dari terlalu kuatnya dominasi korporasi dan oligarkhi dalam penguasaan berbagai sumber daya alam yang ada di Indonesia, aturan tersebut lebih banyak tidak berjalan.

Konsekuensi dari kondisi tersebut di atas adalah munculnya berbagai persoalan lingkungan dalam skala luas. Data dari BNPB menunjukkan bahwa tren bencana dari 2008 hingga tahun 2017 didominasi oleh bencana hidrometeorologi (sekitar 95\%), yaitu bencana yang dipengaruhi cuaca dan sisanya (5\%) adalah bencana yang bersifat geologis (BNPB 2018). Hal ini jelas menunjukkan bahwa telah terjadi krisis ekologi di Indonesia, yang apabila hal ini terus dibiarkan akan membuat terjadinya 
krisis ekologi dalam skala luas. Oleh karena itu, perlu upaya peninjauan kembali atas spirit modernitas yang diadopsi pola pengelolaan lingkungan hidup dan sumberdaya yang ada, dengan harapan kondisi akan menjadi lebih memiliki peluang di masa depan.

\section{Akar Persoalan Krisis Ekologi}

\section{Antroposentrisme dalam Rasionalitas Modern}

Cogito ergo Sum, aku berpikir maka aku ada. Gagasan Rene Descartes ini menandai perubahan paradigmatik dalam menentukan relasi manusia dengan sesuatu hal di luar dirinya, termasuk alam. Pola pikir rasional yang dibawa dalam gagasan ini membawa dampak yang sangat luar biasa pada munculnya semangat optimisme pada diri manusia untuk mampu menaklukkan alam. Manusia tidak lagi tunduk pada alam, melainkan manusia dengan rasio yang dimilikinya mampu untuk mengubah alam sesuai dengan kebutuhannya. Alam dan segala hal yang berada di luar diri manusia kemudian ditempatkan sebagai sarana bagi pemenuhan kebutuhan manusia. Pada konteks ini kategori bernilai hanya dimiliki oleh manusia dan tidak yang lain. Inilah sesungguhnya yang menjadi cikal bakal gagasan antroposentrisme.

Antroposentrisme mendasarkan diri pada keyakinan bahwa manusia adalah penguasa dan penentu realitas yang akan menentukan apa yang menjadi dan terjadi pada dirinya. Oleh karena itu segala sesuatu yang berada di luar diri manusia akan diperlakukan sebagai objek yang berfungsi untuk memenuhi kebutuhan diri manusia. Pada konteks ini manusia ditempatkan sebagai pusat alam semesta yang akan menjadi ukuran nilai sehingga segala sesuatu akan dianggap bernilai jika mampu memberikan kemanfaatan bagi manusia. Artinya, alam di dalam dirinya sendiri dipandang tidak memiliki nilai (Keraf 2005:33).

Paradigma antroposentris ini mendasari hampir seluruh model pengelolaan sumber daya alam yang ada. Kondisi ini kemudian mengakibatkan model pengelolan sumber daya yang selalu bercirikan eksploitasi dalam rangka mengejar pertumbuhan ekonomi. Namun, yang perlu digarisbawahi adalah bahwa paradigma antroposentris ini tidak berdiri sendiri, melainkan selalu berjalan seiring dengan proses modernisasi yang mensyaratkan adanya industrialisasi secara masif. Oleh karena itu, pada konteks persoalan lingkungan, pembahasan tentang antroposentrisme tidak akan utuh jika dilakukan dengan tanpa membahas efek industrialisasi dan proses kapitalisasi yang terjadi di dalamnya.

\section{Industrialisasi dan Kapitalisasi: Pemicu Ketimpangan Akses atas Sumber Daya}

Fakta menunjukkan bahwa menurunnya kualitas lingkungan hidup berjalan seiring dengan kemampuan manusia untuk mengeksploitasi alam, yang dalam hal ini akan melibatkan proses pergeseran masyarakat dari tradisional ke modern. Pada masyarakat tradisional alam ditempatkan sebagai penentu realitas sehingga manusia adalah objek dari kekuatan alam. Oleh karena itu, masyarakat tradisional akan berupaya untuk selalu menyesuaikan diri dengan nalar bekerjanya alam. Jika dianalogikan dengan pemikiran Auguste Comte tentang tahapan perkembangan masyarakat, tahap inilah yang disebut dengan tahap metafisik. Apabila dalam tahapan sebelumnya, yaitu tahapan teologis, segala sesuatu yang terjadi diyakini karena adanya kekuatan supranatural yang dimiliki oleh dewa, roh, atau pun Tuhan, pada tahapan metafisik ini manusia mulai meyakini adanya kekuatankekuatan abstrak selain Tuhan, yaitu alam. Sementara itu, masyarakat modern lebih bersifat positifistik. Masyarakat modern meyakini bahwa kekuasaan atas realitas berada di dalam diri manusia itu sendiri, bukan alam. Pada masyarakat modern segala sesuatu yang terjadi di alam dapat dijelaskan secara ilmiah melalui pembuktian empiris, bukan tergantung pada entitas metafisik (Zalta 2018).

Pada konteks inilah kemudian perkembangan ilmu dan teknologi terjadi dengan sangat pesat. Pesatnya perkembangan ilmu pengetahuan dan teknologi tersebut kemudian berjalan seiring dengan perkembangan kemampuan manusia untuk mengubah alam atau lebih tepatnya mengeksploitasi 62 
alam. Proses ini sekaligus mendasari proses terbentuknya kebudayaan modern. Bersama dengan proses ini pula terjadi akumulasi modal dalam cakupan yang lebih luas. Akumulasi modal tersebut berjalan secara terus menerus, khususnya di negara-negara maju, yang tidak jarang hal ini dilakukan melalui proses eksploitasi di negara-negara berkembang.

Proses modernisasi, industrialisasi, dan kapitalisasi yang terjadi secara terus-menerus itu kemudian menyebabkan krisis ekologis yang tidak terhindarkan. Mengapa? Karena pada sistem kapitalisme, faktor-faktor produksi (sumber daya alam, alat-alat produksi, maupun tenaga kerja) akan dikombinasikan sedemikian rupa untuk menciptakan kemungkinan terbesar bagi tercapainya penimbunan keuntungan. Pada sudut pandang ini, sebuah perusahaan yang ingin memiliki masa depan harus memiliki kontrol atas sumber daya dan meningkatkan investasi serta kehadirannya di pasar dunia. Watak dasar kapitalis umumnya tidak terlalu peduli untuk membuat kerja menjadi lebih nyaman atau pun mengharmoniskan produksi dengan keseimbangan alam dan kehidupan manusia. Proses produksi pada prinsipnya hanya peduli untuk menghasilkan nilai tukar maksimal bagi setiap biaya yang dikeluarkan. Prioritasnya adalah untuk menekan biaya produksi serendah mungkin daripada melestarikan keseimbangan ekologis yang biayanya mahal dan kerusakannya tidak akan menjadi beban perusahaan secara finansial. Teknologi kemudian menjadi pilihan praktis untuk dapat mencapai tujuan maksimalisasi keuntungan dan minimalisasi biaya produksi (Gorz 1980:6).

Akan tetapi, pola pikir semacam itu terbukti menimbulkan banyak persoalan. Diawali dengan terbitnya Silent Springs karya Rachel Carson pada tahun 1962 yang menggambarkan kondisi musim semi yang tidak lagi indah, di mana tidak ada lagi tanaman yang dapat tumbuh dan bersemi, tidak ada kicauan burung, tidak ada telur yang menetas, banyak ternak mati di padang rumput, ikan yang mati dalam jumlah ribuan, ibu dan anak mengalami sakit yang misterius, kelumpuhan, dan sebagainya. Carson menggunakan bahasa yang sangat puitis dan indah dalam mendeskripsikan kerusakan lingkungan yang terjadi. Sebagai seorang ilmuwan biologi, Carson meneliti penyebab itu semua adalah penggunakan pestisida sintetis pada awal-awal revolusi hijau di lahan pertanian. Hal ini disebabkan karena pestisida tidak saja mematikan hama tanaman, tetapi juga membunuh burungburung, kupu-kupu, lebah, dan serangga lainnya yang membantu penyerbukan tanaman. Jejak pestisida melalui rantai makanan menjadi eksplanasi dari berbagai kondisi kerusakan lingkungan yang ada. Sebagai contoh, penyemprotan pestisida ternyata tidak hanya menghancurkan serangga, tetapi juga musuh utama serangga, yaitu burung, sehingga ketika terjadi ledakan populasi serangga, jumlah populasi burung tidak seimbang lagi untuk menjadi predator alami mereka. Melalui karyanya ini Carson ingin menekankan pentingnya prinsip kehati-hatian dalam adopsi teknologi karena efek sistemik yang ditimbulkan sangat dimungkinkan berada di luar kendali manusia (Radford 2011).

Kritik terhadap industrialisasi dan kapitalisasi pada peran sertanya yang dominan dalam krisis ekologi juga dapat ditemukan dalam The Limits to Growth. Buku yang terbit pada tahun 1972 ini sebenarnya merupakan hasil penelitian yang dilakukan oleh sekelompok ahli di bawah naungan Massachusetts Institute of Technology (MIT) dengan sponsor dari The Club of Rome. Pada buku tersebut digunakan lima komponen utama kehidupan yang saling terkait untuk menjelaskan kondisi bumi dan daya dukungnya, yaitu populasi dunia, industrialisasi, pencemaran, produksi makanan, serta penipisan atau berkurangnya sumber daya alam (Meadows 1972:89).

Dalam konteks persoalan populasi dunia, pemikiran Meadows selaras dengan pemikiran Thomas Robert Malthus (1798) dalam An Essay on The Principle of Population bahwa pertumbuhan populasi manusia akan senantiasa bersifat geometris (deret ukur), sementara pertumbuhan sumberdaya akan bersifat aritmatis (deret hitung). Oleh karena itu, meskipun pada suatu ketika posisi sumber daya melimpah, tetap saja karena pertumbuhan populasi yang sangat pesat maka akan berakibat pada 
sumber daya menjadi kembali langka dan pada akhirnya tidak akan pernah mampu mencukupi kebutuhan manusia.

Sementara itu industrialisasi sebagai pokok persoalan kedua menyebabkan terjadinya eksploitasi sumber daya alam secara masif. Industrialisasi merupakan motor penggerak utama bagi tercapainya kondisi masyarakat modern yang keberadaannya tidak saja membutuhkan kecukupan modal secara finansial, tetapi juga sumber daya alam. Proses ini sampai sekarang masih terus berjalan seiring dengan masih diadopsinya paradigma pertumbuhan ekonomi. Selain eksploitasi sumber daya alam secara masif, akibat lebih lanjut dari proses industrialisasi adalah munculnya berbagai macam polusi atau pencemaran dan kerusakan lingkungan. Kondisi ini kemudian memunculkan konsekuensi lanjutan berupa kelangkaan sumber daya serta turunnya daya dukung alam atas keberlanjutan kehidupan yang ada di bumi.

Kondisi kelangkaan sumber daya serta turunnya daya dukung bumi tersebut pada tahap lanjut akan menjadi ancaman bagi setiap manusia. Tidak hanya pada sumber daya yang tidak dapat diperbarui, tetapi kondisi kelangkaan juga menyasar berbagai sumber daya yang seharusnya dapat diperbarui. Menurut catatan Homer-Dixon, dkk., kelangkaan sumber daya alam yang dapat diperbarui ini telah mengakibatkan banyak konflik yang menyedihkan di banyak negara berkembang. Konflik-konflik tersebut berpeluang akan menjadi semakin membesar pada dekade yang akan datang, khususnya di negara miskin maupun negara berkembang di mana kelangkaan sumber air, hutan, dan lahan yang subur dikombinasi dengan pesatnya pertumbuhan penduduk yang mengakibatkan situasi menjadi semakin sulit. Sementara itu, berbagai polusi dan pencemaran yang terjadi juga telah menyebabkan rusaknya daya dukung bumi (Homer-Dixon, dkk. 1993:38).

Dari beberapa faktor yang saling berkelindan sebagaimana disebutkan di atas, industrialisasi yang didominasi oleh kelompok pemilik modal menempati posisi yang sangat signifikan. Proses industrialisasi memang melibatkan banyak pihak, tetapi mesin utamanya tetaplah kapital yang ini hanya dimiliki oleh segelintir orang atau kelompok. Meskipun hanya dimiliki oleh segelintir orang, efeknya sangat luar biasa bagi proses eksploitasi sumber daya yang ada. Harus diakui bahwa dalam setiap proses industrialisasi akan mampu menyerap tenaga kerja, tetapi hal itu terkadang tidak sebanding dengan risiko yang muncul pascaberoperasinya sebuah industri. Biaya eksternal yang muncul seringkali jauh lebih besar dari keuntungan sesaat yang diperoleh dari beroperasinya sebuah industri. Hal ini menunjukkan bahwa proses eksploitasi sumber daya yang berjalan seiring dengan industrialisasi dan kapitalisasi akan selalu menyebabkan ketimpangan distribusi manfaat dan resiko antara pemilik modal dengan masyarakat lokal. Ketimpangan distribusi manfaat dan resiko inilah yang kemudian memunculkan "dominasi” antara kelompok manusia yang satu atas kelompok manusia yang lain, yang kemudian berimbas pada semakin kuatnya dominasi manusia atas alam. Ketika kondisi ini semakin tidak terkendali maka dapat dipastikan ekosistem akan rusak dan kestabilan di alam akan musnah. Oleh karena itu, harus ada upaya dari berbagai pihak terkait untuk melihat persoalan ini secara komprehensif, yaitu dengan mempertimbangkan berbagai aspek yang terkait dengan pengelolaan sumber daya.

\section{Krisis Ekologi dan Problem Keadilan Intergenerasi}

Ketika kondisi lingkungan menjadi semakin kritis akibat kualitas lingkungan yang semakin menurun, ketika daya dukung alam semakin terdegradasi, hal ini menimbulkan dampak tidak hanya bagi manusia pada masa sekarang, tetapi juga lebih jauh pada generasi yang akan datang. Persoalan keadilan intergenerasi memang lebih rumit, mengingat kondisinya yang belum nyata eksis karena masih berada jauh di depan. Namun demikian, persoalan ini sesungguhnya memiliki pertautan yang sangat erat dengan kondisi krisis ekologi yang sedang terjadi dewasa ini. 
Istilah generasi yang akan datang (future generations or posterity) sesungguhnya belum lama mulai mendapatkan perhatian yang serius. Salah satu di antaranya adalah dalam pemikiran John Rawls, yang penjelasan mengenai hal ini merupakan bagian yang tidak terpisahkan dari A Theory of Justice yang terbit pada tahun 1971. Pada pemikiran Rawls tersebut dijumpai model pemahaman kontraktarian untuk menjawab pertanyaan tentang justice between generations (Partridge 2003:428).

Pada awalnya, pendekatan kontraktarian Rawls diasumsikan akan gagal dalam menjelaskan konsep tanggung jawab intergenerasi. Hal ini disebabkan karena para pembuat kontrak tersebut tidak berada dalam kehidupan yang sama secara serentak sehingga tidak mungkin untuk dapat dilakukan tawar menawar atau pun kesepakatan yang bersifat timbal balik. Rawls mengakui kesulitan yang akan dijumpai ketika menggunakan pemahaman seperti tersebut di atas. Oleh karenanya, Rawls mengatakan bahwa prinsip-prinsip dasar keadilan intergenerasi tidak dapat dicapai melalui negosiasi dalam kontrak aktual, melainkan kontrak harus bersifat hipotetis.

Penjelasan atas kontrak hipotetis tersebut dibangun melalui eksperimen pemikiran yang rumit, yang disebut Rawls dengan original position (posisi asali) yang berada dalam selubung ketidaktahuan (veil of ignorance). Secara singkat dapat dijelaskan bahwa para pembuat kontrak tersebut dalam menyusun aturan dalam konteks keadilan intergenerasi akan mengabaikan pengetahuan tentang generasi di mana mereka hidup. Aturan keadilan ini dirancang dalam sebuah posisi asali yang nanti akan dapat diberlakukan untuk semua generasi secara adil. Para pihak dalam posisi asali tidak mengetahui seperti apakah kondisi mereka dalam kehidupan nyata, sehingga mereka juga tidak mengetahui apakah aturan yang akan mereka buat itu nantinya akan menjadi beban ataukah manfaat bagi mereka. Oleh karena itu, aturan yang dibuat dalam posisi asali di bawah selubung ketidaktahuan tersebut dipastikan akan adil. Hal ini dari sudut pandang moral akan mengarahkan pada suatu kesimpulan bahwa dalam posisi asali yang tertutup oleh selubung ketidak tahuan maka prinsip yang akan diadopsi adalah yang prinsip yang paling aman untuk posisi sosial dimanapun dan kapan pun.

Selain Rawls, tokoh lain yang juga berbicara tentang keadilan intergenerasi adalah Edith Brown Weiss. Weiss menjelaskan tentang perlunya menetapkan prinsip-prinsip dasar dalam persamaan intergenerasi, bahwa setiap generasi harus meninggalkan kondisi planet yang sama baiknya, seperti halnya ketika generasi mereka menerima sebelumnya. Weiss pada penjelasannya juga sependapat dengan gagasan Rawls tentang veil of ignorance, karena hal ini akan menjamin ketidakberpihakan kelompok tertentu atas generasi tertentu. Menurut Weiss, prinsip ini harus dilakukan tidak hanya dalam lingkup sebuah bangsa, melainkan untuk seluruh bangsa yang ada di muka bumi (Weiss 1992:19-20).

Sehubungan dengan konsep keadilan intergenerasi tersebut di atas, ada pihak yang pesimis menanggapi hal tersebut dengan argumentasi ketidaktahuan. Pada sudut pandang pihak ini sangat tidak mungkin bagi manusia (baik secara individu maupun komunal) untuk mampu menyediakan kondisi yang adil bagi orang-orang pada generasi yang akan datang, yang berada jauh di depan mereka. Hal ini disebabkan generasi yang ada sekarang tidak mengetahui apa sesungguhnya yang dibutuhkan oleh generasi yang akan datang, sehingga bagi mereka yang berada pada sudut pandang pesimis ini mengklaim bahwa tidak mungkin bagi generasi sekarang untuk meramalkan hal-hal yang menjadi kebutuhan generasi yang akan datang. Karena tidak dimilikinya pengetahuan atas generasi yang akan datang, tidak mungkin juga untuk membuat ketentuan-ketentuan yang akan memengaruhi kehidupan mereka.

Argumen tersebut di atas sesungguhnya dapat dengan mudah dipatahkan karena sesungguhnya ada beberapa fakta mendasar yang dapat diketahui tentang generasi yang akan datang, yaitu generasi yang 
akan datang tentunya tetaplah manusia yang membutuhkan kondisi biotik yang layak untuk menjaga kesehatan mereka. Generasi yang akan datang tersebut hanya dapat hidup dan berkembang ketika terdapat ekosistem yang berfungsi secara baik. Selain itu, generasi yang akan datang sesungguhnya juga akan berposisi sebagai agen moral sebagaimana generasi sekarang, yang berarti bahwa mereka akan hidup dan sadar diri, memiliki perasaan tentang diri mereka sendiri dan orang lain sebagai makhluk berkelanjutan dengan kapasitas untuk memilih di antara masa depan alternatif. Mereka juga akan dilengkapi dengan kapasitas untuk berpikir secara abstrak sebagaimana generasi sekarang sehingga juga akan bertindak berdasarkan prinsip-prinsip tertentu. Oleh karena itu, generasi yang akan datang nantinya juga akan terikat oleh kategori-kategori moral yang lazim tentang hak, tanggung jawab, dan tuntutan keadilan, sebagaimana generasi sekarang (Partridge 2003:434).

Persoalan yang lebih dominan dalam konteks keadilan intergenerasi sesungguhnya terletak pada problem motivasi dalam kapasitas yang dimiliki oleh manusia. Kapasitas yang dimaksudkan di sini tidak sekadar dimaknai sebagai kapasitas dalam konteks teknologi untuk mencegah munculnya implikasi jangka panjang atas semua tindakan yang dilakukan manusia. Kapasitas dalam konteks ini juga mengacu pada kondisi psikologis yang mengarahkan seseorang untuk mematuhi sedemikian rupa atau mampu bertahan pada komitmen yang dibangun.

Norman Care, misalnya, menjelaskan bahwa ada keraguan yang besar terkait problem motivasi atas apa yang dituntut moralitas terhadap generasi yang akan datang. Hal ini disebabkan tidak adanya ikatan cinta atau kepedulian antara generasi sekarang dengan generasi yang akan datang, yang posisinya jauh di depan. Selain itu, juga karena tidak adanya ikatan komunitas, sehingga tidak ada rasa memiliki sesuatu hal secara bersama. Kondisi inilah yang menyebabkan tidak munculnya rasa atau pun motivasi berbagi nasib secara luas dan tidak terbatas. Motivasi semacam ini dianggap sebagai tidak lazim sehingga penanamannya akan membutuhkan perombakan beberapa unsur utama dalam masyarakat (Van De Veerand Pierce 2003:432).

Berbeda dengan pemikiran tersebut di atas, Partridge (1981:204) memberikan jawaban secara lebih positif atas pertanyaan motivasi tersebut di atas, yaitu kepedulian terhadap generasi yang akan datang sesungguhnya merupakan sifat dasar manusia yang muncul melalui proses pematangan dan pemahaman atas (a) asal mula konsep diri; (b) objektifikasi nilai, yaitu persepsi atas nilai sebagai sesuatu yang berada dalam objek yang bernilai; dan (c) kesadaran universal tentang kefanaan seseorang. Semua ini mengarah pada kondisi untuk meyakini bahwa entitas ini akan terus berkembang melampaui rentang masa hidup seseorang. Melalui proses transendensi diri akan dapat dipahami bahwa kehidupan yang paling memuaskan akan terwujud dalam aktivitas dan kepedulian yang diarahkan keluar. Oleh karena itu, setiap tindakan yang dilakukan semestinya tidak semata-mata demi kepentingan terbaik diri sendiri, melainkan demi kepentingan terbaik semua orang yang dengan jalan itu kepentingan diri sendiri akan turut terakomodasi.

\section{Prinsip-prinsip Dasar Politik Pengelolaan Lingkungan: Upaya untuk Mewujudkan Kondisi ke Arah Keadilan Intergenerasi}

Berdasarkan pemaparan pokok-pokok pikiran tersebut di atas, dapat diketahui bahwa dua pokok persoalan yang harus di atasi untuk keluar dari krisis ekologi yaitu (1) mengubah paradigma pengelolaan sumber daya yang masih antroposentris menjadi lebih bercorak ekosentris, dan (2) menghilangkan ketimpangan akses atas sumber daya serta ketimpangan manfaat dan risiko atas eksploitasi sumberdaya.

Adapun upaya untuk dapat merealisasikan hal tersebut dapat dilakukan melalui reformasi pendidikan dan kelembagaan yang lebih berpihak pada upaya-upaya ke arah terwujudnya keadilan intergenerasi. Oleh karena itu penting pada poin ini upaya untuk memelihara institusi-institusi 66 
keadilan agar dapat berjalan sesuai dengan prinsip-prinsip dasar politik pengelolaan lingkungan. Prinsip-prinsip dasar inilah yang nantinya akan berfungsi sebagai kerangka dasar dalam pengelolaan lingkungan dan sumber daya. Prinsip-prinsip tersebut antara lain:

1. Prinsip kehati-hatian. Prinsip ini mendorong pada upaya untuk sejauh mungkin menghindari berbagai kebijakan yang akan membawa dampak yang merugikan, baik secara langsung maupun tidak langsung. Mekanisme yang dijalankan pada prinsip ini secara spirit sesungguhnya juga mendasarkan diri pada prinsip utilitarian, bahwa kebijakan yang baik adalah yang mampu mempromosikan kebajikan dan meminimalisir keburukan. Apabila kondisi kerusakan adalah sesuatu hal yang masih dapat dihindari, hal ini akan menuntut perhatian moral dari setiap orang untuk dilaksanakan. Berkaitan dengan kebutuhan generasi yang akan datang, jauh lebih mudah untuk menemukan hal-hal apa saja yang menjadi sumber kesengsaraan orang-orang di masa depan. Hal ini disebabkan mereka pun manusia sama halnya dengan generasi sekarang dibandingkan menemukan hal-hal yang menjadi sumber kebahagian mereka. Oleh karena itu, meskipun generasi sekarang tidak tahu secara riil apa yang dibutuhkan oleh generasi yang akan datang, sesungguhnya tetap ada kebutuhan mendasar bagi mereka generasi yang akan datang untuk dapat eksis dan menjalankan kehidupan. Pengetahuan ini menjadi dasar bagi munculnya tanggung jawab moral terhadap generasi yang akan datang. Pengetahuan ini juga yang menjadi dasar dari prinsip kehatihatian dalam setiap kebijakan pengelolaan lingkungan. Oleh karena itu, dalam menjalankan prinsip kehatian-hatian ini, mekanisme yang digunakan semestinya lebih bersifat preventif dan antisipatif, bukan kuratif. Prinsip kehati-hatian ini juga yang memungkinkan dimasukkannya pertimbangan-pertimbangan lain nonekonomi dalam sebuah kebijakan lingkungan hidup, sehingga model kebijakan pengelolaan lingkungan tidak lagi sekadar didasarkan pada logika jangka pendek, melainkan pada logika jangka panjang sehingga pertimbangan atas nilai tidak selalu bersifat cash value.

2. Prinsip inklusifitas dan konektivitas. Prinsip ini menekankan pentingnya melihat persoalan lingkungan sebagai sebuah persoalan yang selalu memiliki keterkaitan dengan berbagai persoalan yang lain, seperti politik, ekonomi, sosial, budaya, teknologi, hukum, dll. Oleh karena itu, pengelolaan lingkungan hidup tidak dapat dilakukan secara eksklusif atau terpisah sama sekali dengan persoalan-persoalan yang lain, yang tidak jarang hal ini melampaui batas-batas administratif kewilayahan.

3. Prinsip sustainabilitas. Prinsip ini menegaskan pentingnya keberlanjutan lingkungan hidup sebagai subjek yang memiliki nilai dalam dirinya sendiri. Aspek sustainabilitas inilah yang akan memberikan daya dukung pada keberadaan manusia baik sekarang maupun yang akan datang.

4. Prinsip keadilan. Prinsip ini menegaskan pentingnya pengelolaan sumber daya alam secara adil, baik dalam distribusi manfaat maupun distribusi resiko, pada generasi sekarang maupun yang akan datang. Ketimpangan pada proses distribusi manfaat dan resiko atas sumber daya tidak hanya akan mengakibatkan konflik, tetapi juga kerusakan atas sumber daya. Di sinilah pentingnya konsep alokasi sumber daya diterapkan, karena melalui proses ini akan dapat diatur sebuah mekanisme distribusi yang adil yang mampu memberikan komitmen pada terwujudnya keadilan, baik intragenerasi maupun intergenerasi. Berbagai persoalan yang muncul dalam pengelolaan lingkungan hidup banyak bersumber dari tidak terpenuhinya prinsip keadilan ini. Pada banyak konflik lingkungan yang terjadi ditemukan fakta bahwa masyarakat selalu dibebani dengan risiko tanpa mendapatkan distribusi manfaat yang memadai. Sementara itu, para pemilik modal sebagai pihak yang lebih dominan menikmati kemanfaatan tanpa menerima resiko atas pengelolaan sumberdaya yang mereka lakukan. Prinsip keadilan ini juga mengarahkan pada pentingnya asas persamaan hukum bagi setiap pihak yang terkait, baik masyarakat, pemerintah, dan juga pihak swasta. Berdasarkan pada prinsip ini, segala tindak pelanggaran dalam kaitannya dengan pengelolaan lingkungan hidup harus diproses secara adil dan transparan.

5. Prinsip partisipasi. Keterlibatan warga negara dalam pengelolaan sumber daya menjadi hal yang tidak dapat ditolak di tengah arus besar demokrasi. Hal ini dilakukan dengan tetap menempatkan 
negara sebagai penanggung jawab utama dalam pengelolaan sumber daya. Negara memang masih memiliki otoritas yang dapat digunakan untuk mengatur dan menyinergikan berbagai kepentingan pengelolaan sumber daya, tetapi hal tersebut dilakukan dengan melibatkan partisipasi warga negara secara aktif. Prinsip partisipasi ini lebih mengedepankan peran masyarakat dibandingkan korporasi dalam pengelolaan sumberdaya. Melalui prinsip partisipasi ini diharapkan akan terpenuhi keadilan dalam proses distribusi manfaat maupun resiko, sehingga harapannya akan meminimalkan konflik sumber daya. Selain itu, partisipasi warga masyarakat akan memberikan dampak positif bagi upaya pemerintah untuk menjaga kelestarian sumber daya mengingat potensi kearifan lokal yang ada pada setiap masyarakat. Untuk mendukung berjalannya prinsip ini diperlukan penyiapan kondisi masyarakat terlebih dahulu melalui edukasi, sehingga proses partisipasi tersebut dapat dijalankan dengan baik dan tidak memunculkan problem baru.

Melalui adopsi prinsip-prinsip dasar tersebut dalam berbagai kebijakan politik pengelolaan lingkungan diharapkan kondisi ke arah perubahan yang lebih ekosentris dan memenuhi aspek keadilan lingkungan dapat terwujud. Dengan demikian, secara perlahan namun pasti, komitmen ke arah terwujudnya keadilan intragenerasi dan intergenerasi dapat terlaksana.

\section{SIMPULAN}

Berdasarkan pemaparan tersebut di atas dapat diambil simpulan sebagai berikut, bahwa terjadinya krisis ekologi disebabkan oleh rasionalitas modern dengan pola pikir antroposentris yang berjalan seiring dengan industrialisasi dan kapitalisasi. Proses ini kemudian menyebabkan terjadinya ketimpangan distributif di masyarakat, yang menimbulkan dominasi manusia atas manusia yang lain, serta dominasi manusia atas alam. Dua hal ini sesungguhnya berjalan paralel. Apabila kondisi ini dibiarkan terus berlanjut, akan menjadi ancaman bagi generasi sekarang terlebih lagi generasi yang akan datang. Untuk itu, perlu dilakukan berbagai upaya untuk menghilangkan dua dominasi tersebut yang di antaranya dapat dilakukan melalui reformasi pendidikan dan kelembagaan. Reformasi pendidikan akan menyasar problem paradigmatik antroposentrisme, sedangkan reformasi kelembagaan akan menyasar problem ketimpangan distributif atas sumber daya. Pada domain reformasi kelembagaan, dibutuhkan prinsip-prinsip dasar politik pengelolaan lingkungan yang meliputi prinsip kehati-hatian, keadilan, partisipasi, inklusivitas, konektivitas, dan sustainabilitas. Melalui adopsi prinsip-prinsip tersebut diharapkan berbagai kebijakan pengelolaan lingkungan di Indonesia akan lebih mengarah pada terwujudnya keadilan intergenerasi.

\section{DAFTAR PUSTAKA}

Alase, Abayomi. 2017. "The Interpretative Phenomenological Analysis (IPA): A Guide to A Good Qualitative Research Approach.” International Journal of Education and Literacy Studies 5 (2). doi: 10.7575/aiac.ijels.v.5n.2p.9

Bakker, Anton dan Achmad Charis Zubair. 1990. Metodologi Penelitian Filsafat. Yogyakarta: Kanisius.

BNPB. 2018. “Tren Kejadian Bencana 10 Tahun terakhir (2008-2017).” https://bnpb.cloud/dibi/.

Fakih, Mansour. 2006. Runtuhnya Teori Pembangunan dan Globalisasi. Yogyakarta: Pustaka Pelajar dan Insist Press.

Forest Watch Indonesia. 2018. Deforestasi Tanpa Henti: Potret Deforestasi di Sumatera Utara, Kalimantan Timur, dan Maluku Utara. Bogor: Forest Watch Indonesia.

Gorz, Andre. 2011. Anarki Kapitalisme. Yogyakarta: Resist Book. 
Hidayat, Herman. 2011. Politik Lingkungan: Pengelolaan Hutan Masa Orde Baru dan Reformasi. Jakarta: Yayasan Pustaka Obor.

Homer-Dixon, dkk. 1994. "Environmental Scarcities and Violent Conflict: Evidence from Cases." International Security 19 (1):5-40.

Keraf, A. Sonny. 2005. Etika Lingkungan. Jakarta: Penerbit Buku Kompas.

Maimunah, Siti. 2018. "Rezim Ekstraksi, Oligarki, dan Lubang Tambang". https://www.mongabay.co.id/2018/11/07.

Meadows, Donella H. et al. 1972. The Limits to Growth. New York: Universe Books.

Partridge, Ernest. 2003. "Future Generation." Dalam The Environmental Ethics and Policy Book. Canada: Wadsworth.

Radfords, Tim. 2011. "Silent Spring by Rachel Carson review". The Guardian, 30 September. https://www.theguardian.com/science/2011/sep/30/silent-spring-rachel-carson-review.

Rawls, John. 1971. A Theory of Justice. Cambridge: Harvard University Press.

Rostow, W. W. 1959. "The Stages of Economic Growth.” The Economic History Review New Series 12 (1):1-16.

Utami, Rani, dkk. 2017. "Dampak Ekonomi dan Lingkungan Ekspansi Perkebunan Kelapa Sawit (Studi Kasus: Desa Penyabungan Kecamatan Merlung, Kabupaten Tanjung Jabung Barat, Jambi)." Jurnal Ilmu Pertanian Indonesia 22 (2): 115-126.

Walhi. 2018. “Tinjauan Lingkungan Hidup 2018.” https://walhi.or.id/wpcontent/uploads/2018/12/Layout_Tinjauan-Lingkungan-2018.pdf

Weiss, Edith Brown. 1992. "In Fairness to Future Generations and Sustainable Development." American University International Law Review 8 (1):19-26.

Van De Veer, Donald, and Christine Pierce. 2003. The Environmental Ethics and Policy Book. Canada: Wadsworth.

Zalta, Edward N. (ed.). 2018. “Auguste Comte.” https://plato.stanford.edu/archives/sum2018/ entries/comte/. 